\title{
BACTERIA ISOLATED FROM A SUGARCANE AGROECOSYSTEM: THEIR POTENTIAL PRODUCTION OF POLYHYDROXYALCANOATES AND RESISTANCE TO ANTIBIOTICS
}

\author{
Teresa Cristina S. de Lima ${ }^{1}$; Breno M. Grisi²; M. Christina M. Bonato ${ }^{{ }^{*}}$ \\ ${ }^{1}$ Departamento de Biologia Molecular. ${ }^{2}$ Programa Regional de Pós-Graduação em Desenvolvimento e \\ Meio Ambiente-PRODEMA, Universidade Federal da Paraíba, João Pessoa, PB, Brasil.
}

Submitted: November 06, 1998; Approved: July 30, 1999.

\begin{abstract}
In this investigation, a sugarcane agroecosystem at a coastal tableland, in the northeast of Brazil, was screened to obtain bacteria strains able to synthesize poly- $\beta$-hydroxyalkanoates (PHA), using sucrose as the main carbon source. The potential to synthesize PHA was tested qualitatively by Sudan Black staining of colonies growing in different carbon sources: sucrose, glucose, fructose, propionate and cellulose. In a typical sugarcane crop management system, the plantation is burned before harvesting and vinasse, a by-product of alcohol production, is used in a fertirrigation system causing, probably, selective pressures on the microbiota of natural environments. Eighty-two bacteria strains, belonging to 16 different genera and 35 different species, were isolated. The data showed that 11 strains ( $c a 13 \%$ ), nine of which belonging to the genus Pseudomonas, presented a strong Sudan Black staining in several carbon sources tested and, simultaneously, showed multiple resistance to antibiotics. Resistance to antibiotics is an advantageous feature for the biotechnological production of PHAs. The total number of isolates with multiple resistance to antibiotics was 73 , and $38 \%$ of them belong to the genus Pseudomonas. Among the isolates, $\mathrm{ca} 86 \%$ and $43 \%$ grew in the presence of $10-100 \mathrm{U} / \mathrm{ml}$ of penicillin and/or $100-300 \mathrm{mg} / \mathrm{ml}$ of virginiamycin, respectively. These antibiotics are utilized in the alcohol distillery we investigated. The results suggest that some agroecosystem environments could be considered as habitats where bacteria are submitted to nutritional unbalanced conditions, resulting in strains with potential ability to produce PHAs, and also, to an increase in the microbial diversity.
\end{abstract}

Key words: soil bacteria, poly- $\beta$-hydroxyalkanoate, PHA, resistance to antibiotics, sugarcane agroecosystem, vinasse

\section{INTRODUCTION}

Poly- $\beta$-hydroxyalkanoic acids (PHA) are biodegradable polymers that accumulate in the citosol of microbial cell, as granules, under unbalanced growth conditions with high $\mathrm{C}: \mathrm{N}$ ratio in the medium. $\mathrm{C}_{4}$ to $\mathrm{C}_{18}$ hydroxyalkanoates can be the monomers of different polymers. The first and more abundant PHA found in the microbial biomass was poly$\beta$-hydroxybutirate (PHB) which under limiting environmental conditions may constitute as much as $90 \%$ of the dry cell weight $(11,27)$. A biodegradable plastic with the registered trade name BIOPOL is already industrially produced by Imperial Chemical

\footnotetext{
* Corresponding author. Mailing address: Departamento de Biologia Molecular/CCEN/UFPb, CEP 58059-900, João Pessoa, PB, Brasil. Fax: (+5583) 216-7407. E-mail: cbonato@netwaybbs.com.br
} 
Industries (ICI), of England, as the copolymer poly-3HB/poly-3HV which is less brittle then PHB and has been used as packaging material. The ICI obtain copolymers from mutant strains of Alcaligenes euthrophus $\mathrm{H} 16$, using glucose as main carbon source (5). However, glucose is an expensive substrate for producing biodegradable plastic in industrial scale. Alcaligenes latus is able to produce PHB from sucrose, a cheaper substrate, but in smaller amount than A. eutrophus. Thus, other carbon sources like sodium propionate, fructose, valerate, octanoate, etc have been tested for PHA production, as well as the expression of the structural genes for the key enzymes of PHA synthesis from Alcaligenes eutrophus in other organisms, such as $E$. coli and $S$. cerevisiae $(2,14,25)$.

Antibiotic is considered, in ecological terms, a natural product of microorganisms, synthesized as a secondary metabolite, when excess substrate concentration is available. They are produced mainly by actinomycetes and they are widespread, though evidences of their production in the environments are considered to be limited (33), but they are forthcoming $(9,17,29)$. Besides the production of antibiotics by the microbiota in natural environments, it is quite impressive nowadays the general use of antibiotics in many activities leaded by man, as animal husbandry, agriculture, hospitals and prophylaxis. This extensive and careless usage of antibiotics has encouraged growth of resistant strains leading to an imbalance in prior relationships between susceptible and resistant bacteria $(6,13)$. The resistance strategies used by bacteria can be either by mutation or by plasmid acquisition and the seletive pressure exerted by the presence of the antibiotic will induce resistance to antimicrobial agents among bacteria. Efficient transfer of $\mathrm{R}$ plasmids between bacteria of diverse origin under simulated natural conditions, even in the absence of antimicrobial agents, demonstrate that $\mathrm{R}$ plasmids can spread among bacterial strains of humans, animal, and fish origins that are unrelated either evolutionarily or ecologically (10). Transformation and transduction are, besides conjugation, also important mechanisms of gene transfer in the environment (31). Data confirm that the more frequent antibiotic-resistant strains correspond to the commonest and largest amounts of antibiotics produced and used commercially (16). It was suggested (32) that, in tropical soils, resistant microbial population to antibiotics may be selected from the natural soil microbiota upon contact with these compounds. The resistance to antibiotics would be an advantage for PHA industrial production, once the bacterium that produces this compound could be cultivated free of competitors.

In the northeast of Brazil, the sugarcane is an extensive cash crop plantation spread over many diverse soil ecosystems. One of the most utilized of such ecological systems is the coastal tableland (or 'tabuleiro', as it is named in this part of Brazil). In a typical sugarcane crop management system, every plantation is burned before harvesting, for economical reasons. The vinasse generated as a by-product of alcohol distillery (for every liter of alcohol produced, 11-15 liters of vinasse are discharged to wastewater stabilization ponds), is used in a fertirrigation system, where $300-600 \mathrm{~m}^{3}$ of the wastewater are spread per hectare, before sugarcane crop renovation. Some soil, chemical, physical and ecological implications of this process have been commented elsewhere $(15,28)$. The distillery here studied, produced 56 million liters of alcohol, from August/1992 to March/1993, which means that at least 616 millions liters of vinasse should be recycled in the sugarcane agroecosystem. In the cultivated area of the Usina Japungu ( $\mathrm{ca} 13$ thousands hectares), 3 thousands hectares are fertirrigated with wastewater containing vinasse, once a year, before sugarcane crop renewal. In the fermentors of the distillery (with capacity of 350,000-550,000 liters), variable quantities of antibiotics are used for controlling bacteria populations that compete with Saccharomyces cerevisae for the sucrose of the sugarcane juice. The crop management and processes above described, we believe, contribute to likely selective pressures on the microbiota of natural environments, with differing consequences on microbial populations involved in biogeocycling of essential nutrients to sugarcane plantation. The poor tablelands soils, whose acid pH (5.0 to 5.5) and low nutrients contents are limiting factors to productivity, may be particularly affected by this crop management system, once many hectares of these ecosystems have been abandoned as unproductive, when yield decreases to less than $40 \mathrm{Mg}$ of sugarcane. $\mathrm{ha}^{-1} \cdot \mathrm{yr}^{-1}$. Physical and chemical soil properties seem not to change over some time of cropping; and vinasse, used for fertirrigation, showed to benefit the microbial biomass, in one year observation (15). However, intensive sugarcane cultivation and vinasse effect on soil properties, in a long-term basis, lack further investigations. The possible relation between environments under stress or strong perturbation and 
the biodiversity increase, is another ecological parameter that has been investigated by some authors $(4,30)$ and is also considered in the present study.

In the present investigation, a screening of bacteria living in environments under anthropic pressure in the sugarcane agroecosystem was performed, searching for a) strains with potential to produce PHA using different carbon sources, mainly sucrose; b) strains with multiple resistance to antibiotics and c) microbial diversity of the isolates in an attempt to use these parameters as bioindicators of anthropic pressure on natural microbiota of diverse environments, in the sugarcane agroecosystem.

\section{MATERIALS AND METHODS}

Environment selected. The investigations were performed over two years (1992-94) in the Usina Japungu, an alcohol distillery situated in the municipality of Santa Rita, Paraíba State, Brazil. The local climate type is As' of Köppen classification, hot and humid, and the annual mean rainfall is 1,640 $\mathrm{mm}$. The soil here studied is an oxisol (15). A large and a small stabilization ponds were investigated. The large one receives vinasse from the fermentors and water used for washing the sugarcane before being processed. The small one receives vinasse only. The temperature of the wastewater in the stabilization pond, measured at 10:30, in May 23rd, 1994, was $37^{\circ} \mathrm{C}$. The vinasse as an effluent, coming out straight from the fermentors, reaches a temperature between 80 and $90^{\circ} \mathrm{C}, \mathrm{BOD}_{5} 20,000$ to $35,000 \mathrm{mg} / \mathrm{L}, \mathrm{pH} 3.6$ to 4.0 and total solids $21.8 \mathrm{~g} / \mathrm{L}$. Vinasse applied to soil ( $c a 195 \mathrm{~m}^{3}$.ha-1) supplies twice more $\mathrm{K}$ than the amount required by sugarcane plantation, therefore, a serious threat to soil salinization (15). The samples collected (Group A) and the field experiments carried out in the area we investigated (Group B) are organized in distinct types as described. Group A: samples collected from soil, from the borders of the wastewater stabilization pond and from the wastewater itself, numbered from I to VII. I) Soil amended with sugarcane bagass (20 cm depth); II) soil amended with sugarcane bagass and other organic residues from the distillery $(10 \mathrm{~cm}$ depth $)$; III) soil amended with the wastewater (10 cm depth); IV) soil from the borders of the wastewater stabilization pond, in a place with a mixture locally named 'gelose', which means hydrogel or agar; V) soil from the borders of the stabilization pond, in a place covered temporarily by the wastewater; VI) vinasse collected straight from the fermentors; VII) wastewater from the stabilization pond. Group B: field experiments, where small pieces of sugarcane into nylon bags (45 $\mu \mathrm{m}$ mesh size) were buried in several soil environments or submersed in the large and in the small stabilization ponds. These samples were numbered from VIII to XII. VIII) samples from the borders of the large stabilization pond $(20 \mathrm{~cm}$ depth), in a place covered temporarily by the wastewater; IX) samples from the borders of the large stabilization pond (10 $\mathrm{cm}$ depth), in a place covered permanently by the wastewater; $\mathrm{X}$ ) samples from the soil of sugarcane plantation $(10 \mathrm{~cm}$ depth), not burned before harvesting; XI) samples from the soil of sugarcane plantation $(10 \mathrm{~cm}$ depth), burned before harvesting; XII) samples submersed in the small stabilization pond.

Samples processing and bacteria identification. Soil samples $(2 \mathrm{~g})$ and sugarcane pieces contained in the nylon bags ( $2 \mathrm{~g})$, were processed as follow (19): they were mixed in $250 \mathrm{ml}$ of water $(6,000$ r.p.m.) for $2 \mathrm{~min}$. Wastewater and vinasse samples were mixed manually for $2 \mathrm{~min}$. Serial dilutions were performed using buffers with the same $\mathrm{pH}$ of the samples collected from the environments (7). Soil $\mathrm{pH}$ was determined in water $(1: 2.5 \mathrm{v} / \mathrm{v})$, according to Allen et al. (1). Aliquots from each dilution were transferred to nutrient broth (NB) and incubated at $30^{\circ} \mathrm{C}$ and $37^{\circ} \mathrm{C}$. After $24 \mathrm{~h}$ the cultures were streaked in agar nutrient and incubated to form isolated colonies (19). The colonies were characterized morphologically and then replicated for further biochemical tests, for identifying the isolated species $(8,26)$. Standards strains from the collection of the Departamento de Antibióticos, Universidade Federal de Pernambuco were used for comparison: Bacillus subtilis (DAUFPE-16; Waksman, USA); B. anthracis (DAUFPE-09; Escola Nacional de Ciências Biológicas, México), B. cereus (DAUFPE-11; Departamento de Antibióticos, UFPE), and Pseudomonas aeruginosa (DAUFPE-39; Instituto Tecnológico-2633).

Detection of potential PHA production. Colonies were grown in minimum unbalanced agar medium (MUA): $\mathrm{NH}_{2} \mathrm{HPO}_{4} \cdot 7 \mathrm{H}_{2} \mathrm{O}, 6.7 \mathrm{~g} / \mathrm{L} ; \mathrm{KH}_{2} \mathrm{PO}_{4}$, $1.5 \mathrm{~g} / \mathrm{L} ;\left(\mathrm{NH}_{4}\right)_{2} \mathrm{SO}_{4}, 0.5 \mathrm{~g} / \mathrm{L} ; \mathrm{MgSO}_{4} .7 \mathrm{H}_{2} \mathrm{O}, 0.2 \mathrm{~g} / \mathrm{L}$; $\mathrm{CaCl}_{2} .2 \mathrm{H}_{2} \mathrm{O}, 0.01 \mathrm{~g} / \mathrm{L} ; \mathrm{Fe}(\mathrm{III}) \mathrm{NH}_{4}$ citrate, $0.06 \mathrm{~g} / \mathrm{L}$ and trace element solution, $1 \mathrm{ml} / \mathrm{L}$. Trace element solution contained: $\mathrm{H}_{3} \mathrm{BO}_{3}, 0.3 \mathrm{~g} / \mathrm{L} ; \mathrm{CoCl}_{2} .6 \mathrm{H}_{2} \mathrm{O}$, $0.2 \mathrm{~g} / \mathrm{L} ; \mathrm{ZnSO}_{4} .7 \mathrm{H}_{2} \mathrm{O}, 0.1 \mathrm{~g} / \mathrm{L} ; \mathrm{MnCl}_{2} .4 \mathrm{H}_{2} \mathrm{O}$, 
$0.03 \mathrm{~g} / \mathrm{L} ; \mathrm{NaMoO}_{4} \cdot 2 \mathrm{H}_{2} \mathrm{O}, 0.03 \mathrm{~g} / \mathrm{L} ; \mathrm{NiCl}_{2} .6 \mathrm{H}_{2} \mathrm{O}$, $0.02 \mathrm{~g} / \mathrm{L}$ and $\mathrm{CuSO}_{4} .5 \mathrm{H}_{2} \mathrm{O}, 0.01 \mathrm{~g} / \mathrm{L}$. The carbon source (sucrose, glucose, fructose, sodium propionate or carboxy methyl cellulose) was added at $5.0 \mathrm{~g} / \mathrm{L}$ (22, modified). Agar was added at $15 \mathrm{~g} / \mathrm{L}$. Potential PHA production was detected after five days incubation at 30 or $37^{\circ} \mathrm{C}$, by Sudan Black (SB) staining of the colonies. Briefly: a $0.02 \%$ SB solution in ethanol $96 \%$ was spread over the colonies for 30-60 min, discarded and washed with ethanol 96\% (24). Dark blue stained strains were compared to standards strains of Alcaligenes eutrophus DSM 545 and A. latus 1023 (from IPT-Instituto de Pesquisas Tecnológicas, São Paulo).

Antibiotics screening procedure. Plate dilution technique, in nutrient agar (NA), was used for determining the levels of the strains resistance to the following antibiotics and respective concentrations (23): kanamycin sulphate, $\mathrm{km}, 20 \mu \mathrm{g} / \mathrm{ml}$ (Sigma); tetracyclin, tc, $10 \mu \mathrm{g} / \mathrm{ml}$ (Briston); ampicillin, amp, 50-100-150-200 $\mu \mathrm{g} / \mathrm{ml}$ (Wyeth); streptomycin sulphate, sm, $20 \mu \mathrm{g} / \mathrm{ml}$, (Inlab); nalidixic acid, nal, $20 \mu \mathrm{g} / \mathrm{ml}$ (Sigma). The antibiotics virginiamycin, virg, and penicillin, pen, from SmithKline Beecham, were a gift from Usina Japungu. The maximal concentration used in the alcohol distillery, for all antibiotics, was $20 \mu \mathrm{g} / \mathrm{ml}$. In this work, the final concentrations for virginiamycin were $100-150-300 \mu \mathrm{g} / \mathrm{ml}$ and for penicillin were $1-10-100 \mathrm{U} / \mathrm{ml}$.

\section{RESULTS AND DISCUSSION}

Bacteria strains with potential PHA production. Table 1 shows the bacteria strains (Group A) isolated from the environments studied, their ability to grow in different carbon sources and their multiple resistance antibiotic phenotype. From the 40 isolates, 27 strains grew well in sucrose, 32 in glucose, 31 in fructose, 22 in propionate and 7 in cellulose. Samples from sites IV and VII presented the highest number of strains, belonging to 10 and 8 different species respectively. $36 \%$ (site IV) and 67\% (site VII) of the strains grew well in sucrose, glucose, fructose, and propionate. Positive Sudan Black (SB) staining in the distinct carbon sources is shown in Fig. 1, except for cellulose, because bacteria growing in this carbon source showed very weak staining. Although 85\% (34 strains) of the isolates in Group A can be SB positive, a wide range of tint can be observed and only $25 \%$ (10 strains) were in the

\section{Group A GroupB}

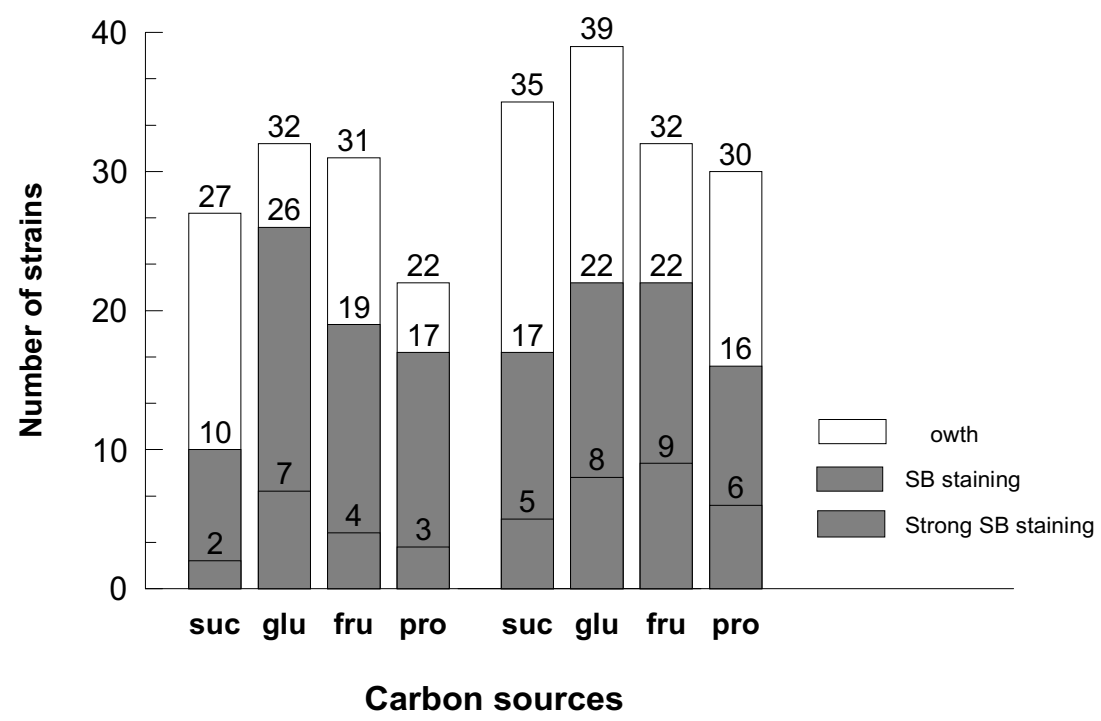

Figure 1 - Growth and intensity Sudan Black (SB) staining of 82 strains growing in minimum unbalanced agar medium plus sucrose, glucose, fructose or sodium propionate $(5.0 \mathrm{~g} / \mathrm{L}$ ), stained with a $0.02 \%$ ethanolic SB solution (the numbers on the top of the bars indicate the number of strains). 
Table 1 - Group A strains (types I to VII) isolated from the sugar cane agroecosystem: growth in different carbon sources and resistance to antibiotics

\begin{tabular}{|c|c|c|c|c|c|c|c|c|c|c|c|c|c|c|}
\hline \multirow{2}{*}{ Types } & \multirow{2}{*}{ Strains } & \multirow{2}{*}{ Species } & \multicolumn{5}{|c|}{ Growth in Carbon Sources ${ }^{1}$} & \multicolumn{7}{|c|}{ Resistance to antibiotics $(\mu \mathrm{g} / \mathrm{ml})^{2}$} \\
\hline & & & suc & glu & fru & pro & cel & amp & virg & pen & $\mathrm{sm}$ & $\mathrm{km}$ & tc & nal \\
\hline \multirow[t]{5}{*}{ I } & AS1 & Enterobacter cloacae & + & + & + & - & - & 150 & 300 & 100 & - & - & - & - \\
\hline & AS2 & Enterobacter cloacae & + & + & + & - & - & 150 & 300 & 100 & - & - & - & - \\
\hline & AS3 & Enterobacter cloacae & + & + & + & - & - & 150 & 300 & 100 & - & 20 & - & - \\
\hline & AS4 & Enterobacter cloacae & + & + & + & w & $\mathrm{w}$ & 150 & 300 & 100 & - & 20 & - & - \\
\hline & AS11 & Pseudomonas sp. & - & $\mathrm{w}$ & + & $\mathrm{w}$ & - & 150 & - & 100 & - & - & 10 & 20 \\
\hline \multirow[t]{3}{*}{ II } & AS5 & Enterobacter cloacae & + & + & + & - & - & 100 & 300 & 100 & - & - & - & - \\
\hline & AS7 & Pseudomonas vesicularis & + & + & + & + & - & 50 & - & 100 & - & - & - & - \\
\hline & AS10 & Pseudomonas picketii & - & + & + & + & - & 150 & 150 & 100 & 20 & 20 & 10 & - \\
\hline \multirow[t]{6}{*}{ III } & AS12 & Pseudomonas picketii & + & + & + & - & - & 150 & - & 100 & 20 & 20 & - & - \\
\hline & AS12A & Pseudomonas picketii & - & + & + & + & - & 50 & 300 & 100 & 20 & - & - & - \\
\hline & AS13 & Bacillus anthracis & + & + & + & - & - & - & - & - & - & - & - & - \\
\hline & AS13A & Sporosarcina ureae & + & + & $\mathrm{w}$ & - & - & - & - & - & - & - & - & 20 \\
\hline & AS14 & Pseudomonas picketii & $\mathrm{w}$ & $\mathrm{w}$ & + & + & $\mathrm{w}$ & 150 & 300 & 100 & 20 & 20 & 10 & 20 \\
\hline & AS14A & Bacillus sphaericus & $\mathrm{w}$ & $\mathrm{w}$ & + & - & + & - & - & 1 & 20 & 20 & - & 20 \\
\hline \multirow[t]{11}{*}{ IV } & AS15 & Pseudomonas delafieldii & + & + & + & + & $\mathrm{w}$ & 150 & - & 100 & 20 & - & - & 20 \\
\hline & AS15A & Pseudomonas syringae & + & + & + & + & - & 150 & 150 & 100 & 20 & 20 & - & - \\
\hline & AS16 & Serratia marcescens & + & + & + & + & $\mathrm{w}$ & 50 & 300 & 100 & - & 20 & 10 & - \\
\hline & AS16A & Burkholderia cepacia* & - & + & - & $\mathrm{w}$ & - & 150 & - & 100 & 20 & 20 & 10 & - \\
\hline & AS17 & Citrobacter freundii & $\mathrm{w}$ & $\mathrm{w}$ & + & + & $\mathrm{w}$ & 50 & 150 & 100 & - & - & - & - \\
\hline & AS17A & Pseudomonas picketii & - & + & - & + & - & - & - & - & - & - & - & - \\
\hline & AS17B & Pseudomonas alcaligenes & - & $\mathrm{w}$ & $\mathrm{w}$ & - & - & 150 & 150 & 10 & - & - & 10 & - \\
\hline & AS17C & Pimelobacter simplex & + & + & + & $\mathrm{w}$ & + & - & - & 10 & - & - & - & 20 \\
\hline & AS18 & Pseudomonas aeruginosa & + & + & + & + & - & 150 & 300 & 100 & 20 & 20 & 10 & 20 \\
\hline & AS18A & Burkholderia cepacia & + & + & w & + & - & 150 & 300 & 100 & 20 & 20 & 10 & 20 \\
\hline & AS18B & Pseudomonas pseudoalcaligenes & - & + & + & + & - & 150 & - & 10 & 20 & - & - & - \\
\hline \multirow[t]{5}{*}{ V } & AS76 & Serratia. marcescens & + & + & + & + & + & 150 & 150 & 100 & 20 & - & 10 & - \\
\hline & AS76A & Citrobacter freundii & $\mathrm{w}$ & $\mathrm{w}$ & + & + & - & 150 & - & 100 & - & - & - & - \\
\hline & AS77 & Pseudomonas alcaligenes & - & + & $\mathrm{w}$ & + & - & 150 & 300 & 100 & 20 & 20 & 10 & 20 \\
\hline & AS78 & Agromyces ramosus & $\mathrm{w}$ & $\mathrm{w}$ & + & $\mathrm{w}$ & - & 100 & - & 10 & - & - & - & - \\
\hline & AS79 & Pseudomonas picketii & + & + & + & + & $\mathrm{w}$ & 150 & 300 & 100 & 20 & 20 & 10 & - \\
\hline VI & AS81 & Bacillus pasteurii & + & + & + & + & $\mathrm{w}$ & - & - & 10 & - & - & - & - \\
\hline \multirow[t]{9}{*}{ VII } & AS44 & Proteus vulgaris & + & + & + & + & $\mathrm{w}$ & 150 & - & 100 & 20 & 20 & - & - \\
\hline & AS44A & $\begin{array}{l}\text { Aeromonas salmonicida } \\
\text { subsp. salmonicida }\end{array}$ & + & + & + & + & + & 200 & 100 & 100 & 20 & 20 & - & - \\
\hline & AS45 & Aeromonas caviae & + & + & + & + & + & 150 & - & 100 & - & - & - & - \\
\hline & AS46A & Pseudomonas succharophila & + & $\mathrm{w}$ & + & + & $\mathrm{w}$ & 200 & - & 100 & 20 & - & - & - \\
\hline & AS46B & Burkholderia cepacia & + & + & + & + & + & 200 & 100 & 10 & - & - & 10 & - \\
\hline & AS47 & Pseudomonas pseudoalcaligenes & + & + & - & $\mathrm{w}$ & - & 50 & - & 10 & - & - & - & 20 \\
\hline & AS47A & Pseudomonas pseudoalcaligenes & + & + & - & $\mathrm{w}$ & - & 50 & - & 100 & - & - & - & - \\
\hline & AS47B & Aeromonas sobria & + & + & + & $\mathrm{w}$ & + & 200 & - & 100 & - & - & - & - \\
\hline & AS48 & Kurthia gibsonii & + & + & - & $\mathrm{w}$ & $\mathrm{w}$ & - & - & - & - & - & - & 20 \\
\hline
\end{tabular}

* Formerly, Pseudomonas cepacia

${ }^{1}$ suc, sucrose; glu, glucose; fru, fructose; prop, propionate; cel, celulose. Strong growth (+); weak (w) and no growth (-);

2 amp, ampicillin; virg, virginiamycin; pen, penicillin; sm, streptomycin; km, kanamycin; tc, tetracyclin; nal, nalidixic acid; (-) no growth in the range of antibiotic concentration used. 
superior limit of the range $(++$ or +++$)$. Among the strains growing in sucrose, glucose, fructose, and propionate, $\mathrm{ca} 7 \%, 22 \%, 13 \%$, and $14 \%$, respectively, are strong SB stained. These strains were found in the sites II, III, IV and VII, from which, four of them having the highest staining, could be potential PHA producers: two Pseudomonas picketii, one Pseudomonas delafieldii, and one Burkholderia (formerly Pseudomonas) cepacia (Table 3). It is noteworthy that $P$. delafieldii is strong SB stained when growing either on sucrose, glucose, fructose or propionate. The environments IV and VII are related, directly or not, to vinasse and, therefore, they are likely under stress.

In Group B (field experiments using sugarcane pieces), from the 42 strains isolated, 35 grew well in sucrose, 39 in glucose, 32 in fructose, and 30 in propionate (Table 2). The highest number of different species was found in samples from sites XI and XII. Also in Group B, 30 strains (71\%) were SB positive in the different carbon sources tested and $\mathrm{ca} 30 \%$ (12 strains) was in the superior limit of the range. Among the strains growing in sucrose, glucose, fructose, and propionate, $\mathrm{ca} 14 \%, 20 \%, 28 \%$, and $20 \%$, respectively, are strong SB stained (Figura 1). Seven of these strains, from field experiments IX, X, XI and XII, could be potential PHA producers: Pseudomonas picketii (3 strains) using propionate as the main C source; Pseudomonas delafieldii (3 strains) using sucrose as the main $\mathrm{C}$ source and glucose, fructose or propionate; and Burkholderia cepacia (1 strain) using glucose and fructose (Table 3 ). Interestingly, from the 10 strains identified in the field experiment XI (sugarcane plantation burned before harvesting), 5 (50\%) were strong SB stained. In the sample from not burned plantation, $25 \%$ of the isolated strains were strong SB stained.

In both Groups $\mathrm{A}$ and $\mathrm{B}$, eleven strains (5P. picketii, 4 P. delafieldii, and 2 Burkholderia cepacia) presented the strongest Sudan Black staining intensity $(+++)$ in the indicated $\mathrm{C}$ source, and simultaneously, showed multiple resistance to antibiotics (Table 3), which may represent an advantage for biotechnological PHB production. The environments III, IV, VI, VII, IX, XI, and XII could be considered as habitats where bacteria are submitted to unbalanced nutritional growth condition, caused by the introduction of vinasse utilized in the fertirrigation and the use of fire in the sugarcane plantation. These environmental conditions could exert a positive selective pressure for potential PHA producers strains. From the 11 strongest SB staining strains, 8 came from these environments ( $\mathrm{ca} 73 \%$ ). Four P. delafieldii strains (AS15, AS60, AS61A, and AS64) were highly SB stained in sucrose, a cheaper $\mathrm{C}$ source, and also, multiresistant to antibiotics, which may represent a good potential for biotechnological purpose. Production of PHAs by $P$. delafieldii has not yet been reported in the literature although synthesis of PHAs is a common feature of pseudomonads when grown on hydrocarbons, and expression of PHA synthase gene from $P$. aeruginosa in $E$. coli leads to PHA accumulation in the cells growing in LB medium containing fatty acids (21).

Bacteria strains antibiotics-resistant. A total number of 35 strains with multiple resistance to antibiotics was isolated from all the environments investigated in Group A. Among these strains, $c a$ $46 \%$ belong to genus Pseudomonas (Table 1). The sets of samples collected from the stabilization pond, IV ('gelose') and VII (wastewater), show high species variability (16 different species) with multiple resistance to antibiotics. These environments, as pointed out in the previous item, are related to vinasse and are possibly under stress. But from the vinasse collected straight from the fermentors (temperature between 80 and $90^{\circ} \mathrm{C}$ ), only a strain of Bacillus pasteurii was isolated, a typical endospore-forming bacterium. The majority of the bacteria strains were resistant to penicillin (90\%) and ampicillin ( $c a$ 82\%) and thirty-three strains were simultaneously amp/ pen-resistant. The percentage of isolates resistant to virg and sm was ca $47 \%$ and $42 \%$ respectively. The percentage of isolates resistant to $\mathrm{km}$, tc or nal is lower than $40 \%$ in each case. From the 22 soil strains related to the large stabilization pond (III, IV, V), ca $45 \%$ showed multiple resistance to five or more antibiotics.

A total amount of 38 strains with multiple resistance to antibiotics was isolated from all the environments investigated in Group B. Among these strains, 34\% belong to genus Pseudomonas (Table $2)$. Variable numbers of strains with multiple resistance were isolated either from restricted environments of the stabilization pond or from soil of burned and unburned sugarcane plantations. Nine strains showed multiple resistance to 5-7 antibiotics, and 7 of them originated from samples X (not burned) and XI (burned). The majority of the bacteria strains was ampicillin-resistant ( $\mathrm{ca}$ 97\%) and penicillinresistant (ca 95\%). Thirty-six strains were simultaneously amp/pen-resistant. Forty-two percent 
Table 2 - Group B strains (types VIII to XII) isolated from the sugar cane agroecosystem: growth in different carbon sources and resistance to antibiotics

\begin{tabular}{|c|c|c|c|c|c|c|c|c|c|c|c|c|c|c|}
\hline \multirow{2}{*}{ Types } & \multirow{2}{*}{ Strains } & \multirow{2}{*}{ Species } & \multicolumn{5}{|c|}{ Growth in Carbon Sources ${ }^{1}$} & \multicolumn{7}{|c|}{ Resistance to antibiotics $(\mu \mathrm{g} / \mathrm{ml})^{2}$} \\
\hline & & & suc & glu & fru & pro & cel & amp & virg & pen & $\mathrm{sm}$ & $\mathrm{km}$ & tc & nal \\
\hline \multirow[t]{7}{*}{ VIII } & AS49 & $\begin{array}{l}\text { Klebsiella pneumoniae } \\
\text { subsp. pneumoniae }\end{array}$ & + & + & + & + & + & 200 & 300 & 100 & - & 20 & - & - \\
\hline & AS50 & Pseudomonas stutzeri & + & + & w & w & - & 200 & - & 100 & 20 & 20 & - & - \\
\hline & AS50A & Pseudomonas delafieldii & + & + & + & + & - & 150 & 100 & 100 & - & - & - & - \\
\hline & AS51 & Klebsiella. pneumoniae & & & & & & & & & & & & \\
\hline & & subsp. pneumoniae & + & + & + & + & + & 200 & 300 & 100 & - & - & - & - \\
\hline & AS51A & Kluyvera cryocrescens & + & + & $\mathrm{w}$ & w & - & 200 & - & 100 & - & - & - & - \\
\hline & AS51B & Pseudomonas pseudoalcaligenes & $\mathrm{w}$ & + & $\mathrm{w}$ & $\mathrm{w}$ & $\mathrm{w}$ & 200 & 150 & 100 & - & - & - & 20 \\
\hline \multirow[t]{9}{*}{ IX } & AS68 & Escherichia hermannii & + & + & + & + & - & 150 & - & 100 & - & - & - & - \\
\hline & AS68A & Bacillus cereus & + & + & + & + & + & 100 & - & 100 & - & - & - & - \\
\hline & AS69 & Bacillus sphaericus & + & + & $\mathrm{w}$ & + & w & - & - & - & - & - & - & 20 \\
\hline & AS69A & Pseudomonas stutzeri & - & $\mathrm{w}$ & $\mathrm{w}$ & + & - & 50 & 100 & 100 & 20 & 20 & - & - \\
\hline & AS70 & Bacillus cereus & + & + & + & + & + & 150 & - & 100 & - & - & - & - \\
\hline & AS70A & Escherichia hermannii & + & + & + & + & w & 100 & - & 100 & - & - & - & - \\
\hline & AS70B & Pseudomonas picketii & + & + & + & + & + & 100 & 150 & 100 & 20 & 20 & - & - \\
\hline & AS71 & Escherichia hermannii & + & + & + & $\mathrm{w}$ & - & 150 & - & 100 & - & - & - & - \\
\hline & AS71A & Bacillus sphaericus & + & + & + & + & $\mathrm{w}$ & - & - & - & - & - & - & 20 \\
\hline \multirow[t]{8}{*}{$\mathrm{X}$} & AS64 & Pseudomonas delafieldii & + & + & + & w & - & 150 & 300 & 100 & - & - & 10 & 20 \\
\hline & AS64A & Serratia marcescens & + & + & + & + & + & 150 & 150 & 100 & - & - & 10 & - \\
\hline & AS65 & Pseudomonas delafieldii & $\mathrm{w}$ & + & + & $\mathrm{w}$ & - & 150 & - & 100 & - & - & 10 & 20 \\
\hline & AS66A & Escherichia coli & + & + & + & + & $\mathrm{w}$ & 100 & - & 100 & - & - & - & - \\
\hline & AS67 & Bacillus cereus & + & + & + & + & + & 150 & - & 100 & - & - & - & - \\
\hline & AS67A & Serratia marcescens & + & + & + & $\mathrm{w}$ & + & 150 & 150 & 100 & 20 & - & 10 & - \\
\hline & AS67B & Pseudomonas picketii & + & + & - & + & w & 150 & 300 & 100 & 20 & 20 & - & 20 \\
\hline & AS67C & Bacillus cereus & + & + & + & + & + & 150 & - & 100 & - & - & - & - \\
\hline \multirow[t]{10}{*}{ XI } & AS72 & Burkholderia cepacia* & + & + & + & + & - & 150 & 300 & 10 & 20 & - & 10 & 20 \\
\hline & AS72A & Aeromonas salmonicida subsp. smithia & + & + & + & + & $\mathrm{w}$ & 150 & - & - & - & - & - & 20 \\
\hline & AS72B & Bacillus larvae & + & + & + & + & + & 150 & - & 10 & & - & - & \\
\hline & AS72C & Enterobacter(Erwinia) nimipressuralis & + & + & + & $\mathrm{w}$ & + & 150 & - & 100 & - & - & - & - \\
\hline & AS73 & Burkholderia cepacia & + & + & + & + & - & 150 & 300 & 100 & 20 & - & 10 & 20 \\
\hline & AS74 & Bacillus cereus & + & + & + & + & + & 150 & - & 100 & - & - & - & - \\
\hline & AS74A & Enterobacter(Erwinia) nimipressuralis & + & + & + & $\mathrm{w}$ & + & 50 & - & 100 & - & - & - & - \\
\hline & AS74B & Enterobacter cloacae & + & + & + & $\mathrm{w}$ & + & 50 & - & 10 & - & - & - & - \\
\hline & AS75 & Pseudomonas picketii & + & + & $\mathrm{w}$ & + & - & 150 & 300 & 100 & 20 & 20 & 10 & 20 \\
\hline & AS75A & Bacillus alcalophilus & + & + & + & - & + & - & - & - & - & 20 & - & 20 \\
\hline \multirow[t]{10}{*}{ XII } & AS60 & Pseudomonas delafieldii & + & + & + & + & + & 150 & - & 100 & 20 & - & - & 20 \\
\hline & AS60A & Pseudomonas syringae & $\mathrm{w}$ & + & - & - & - & 150 & - & 100 & 20 & - & - & 20 \\
\hline & AS61 & Escherichia hermannii & $\mathrm{w}$ & $\mathrm{w}$ & $\mathrm{w}$ & + & - & 150 & 100 & 100 & - & - & - & - \\
\hline & AS61A & Pseudomonas delafieldii & + & + & + & + & + & 150 & - & 100 & - & - & - & 20 \\
\hline & AS61B & Arthrobacter amescens & + & + & + & + & + & - & - & - & - & - & - & - \\
\hline & AS62 & Klebsiella pneumoniae & & & & & & & & & & & & \\
\hline & & subsp. pneumoniae & + & + & + & + & + & 150 & 300 & 100 & - & - & - & - \\
\hline & AS62A & Bacillus cereus & + & + & + & + & + & 50 & - & 100 & - & - & - & - \\
\hline & AS62B & Bacillus coagulans & $\mathrm{w}$ & + & + & + & $\mathrm{w}$ & - & - & - & - & - & - & 20 \\
\hline & AS63 & Pseudomonas aeruginosa & 0 & $\mathrm{w}$ & $\mathrm{w}$ & + & 0 & 150 & 300 & 100 & 20 & 20 & 10 & 20 \\
\hline
\end{tabular}

* Formely Pseudomonas cepacia

${ }^{1}$ suc, sucrose; glu, glucose; fru, fructose; prop, propionate; cel, celulose. Strong growth (+); weak (w) and no growth (-);

2 amp, ampicillin; virg, virginiamycin; pen, penicillin; sm, streptomycin; km, kanamycin; tc, tetracyclin; nal, nalidixic acid; (-) no growth in the range of antibiotic concentration used. 
Table 3 - Bacteria strains isolated from the sugarcane agroecosystem, with their respective potential for producing polyhydroxyalcanoates (Sudan Black stained) in the carbon sources tested, and their resistance to antibiotics.

\begin{tabular}{|c|c|c|c|c|c|c|c|}
\hline \multirow{2}{*}{$\begin{array}{l}\text { Strains } \\
\text { Group A* }\end{array}$} & \multirow{2}{*}{ Source } & \multirow{2}{*}{ Species } & \multicolumn{4}{|c|}{ Carbon Source } & \multirow{2}{*}{ Antibiotics } \\
\hline & & & suc & glu & fru & pro & \\
\hline AS10 & II & P. picketii & - & +++ & - & ++ & $\mathrm{Amp} / \mathrm{Tc} / \mathrm{Sm} / \mathrm{Km} / \mathrm{Nal} / \mathrm{Virg} / \mathrm{Pen}$ \\
\hline AS12 & III & P. picketii & - & ++ & ++ & - & $\mathrm{Amp} / \mathrm{Sm} / \mathrm{Km} / \mathrm{Pen}$ \\
\hline AS12A & III & P. picketii & - & ++ & - & +++ & $\mathrm{Amp} / \mathrm{Sm} / \mathrm{Virg} / \mathrm{Pen}$ \\
\hline AS15 & IV & P. delafieldii & +++ & +++ & +++ & +++ & $\mathrm{Amp} / \mathrm{Sm} / \mathrm{Nal} / \mathrm{Pen}$ \\
\hline AS15A & IV & P. syringae & - & - & ++ & - & $\mathrm{Amp} / \mathrm{Sm} / \mathrm{Km} / \mathrm{Virg} / \mathrm{Pen}$ \\
\hline AS16A & IV & B. cepacia* & - & ++ & - & - & $\mathrm{Amp} / \mathrm{Tc} / \mathrm{Sm} / \mathrm{Km} / \mathrm{Virg} / \mathrm{Pen}$ \\
\hline AS17C & IV & P. simplex & ++ & - & - & - & $\mathrm{Nal} / \mathrm{Pen}$ \\
\hline AS18A & IV & B. cepacia* & - & +++ & - & - & $\mathrm{Amp} / \mathrm{Tc} / \mathrm{Sm} / \mathrm{Km} / \mathrm{Nal} / \mathrm{Pen}$ \\
\hline AS44A & VII & A. salmonicida & - & ++ & - & - & $\mathrm{Amp} / \mathrm{Sm} / \mathrm{Km} / \mathrm{Virg} / \mathrm{Pen}$ \\
\hline AS46A & VII & P. saccharophila & - & - & ++ & - & $\mathrm{Amp} / \mathrm{Sm} / \mathrm{Pen}$ \\
\hline Group B* & & & Suc & Glu & Fru & Pro & \\
\hline AS50A & VIII & P. delafieldii & - & ++ & ++ & ++ & Amp/Nal/Virg/Pen \\
\hline AS 60 & XII & P. delafieldii & +++ & +++ & +++ & +++ & $\mathrm{Amp} / \mathrm{Sm} / \mathrm{Nal} / \mathrm{Pen}$ \\
\hline AS61A & XII & P. delafieldii & +++ & ++ & ++ & +++ & $\mathrm{Amp} / \mathrm{Nal} / \mathrm{Pen}$ \\
\hline AS64 & $\mathrm{X}$ & P. delafieldii & +++ & +++ & +++ & - & $\mathrm{Amp} / \mathrm{Tc} / \mathrm{Sm} / \mathrm{Nal} / \mathrm{Pen}$ \\
\hline AS65 & $\mathrm{X}$ & P. delafieldii & - & ++ & ++ & - & $\mathrm{Amp} / \mathrm{Tc} / \mathrm{Nal} / \mathrm{Virg} / \mathrm{Pen}$ \\
\hline AS67B & $\mathrm{X}$ & P. picketii & - & - & - & +++ & $\mathrm{Amp} / \mathrm{Sm} / \mathrm{Km} / \mathrm{Nal} / \mathrm{Virg} / \mathrm{Pen}$ \\
\hline AS70B & IX & P. picketii & - & ++ & - & +++ & $\mathrm{Amp} / \mathrm{Sm} / \mathrm{Km} / \mathrm{Virg} / \mathrm{Pen}$ \\
\hline AS72 & XI & B. cepacia* & ++ & +++ & +++ & - & $\mathrm{Amp} / \mathrm{Tc} / \mathrm{Sm} / \mathrm{Nal} / \mathrm{Virg} / \mathrm{Pen}$ \\
\hline AS73 & $\mathrm{XI}$ & B. cepacia & - & - & ++ & - & $\mathrm{Amp} / \mathrm{Tc} / \mathrm{Sm} / \mathrm{Nal} / \mathrm{Virg} / \mathrm{Pen}$ \\
\hline AS74A & XI & E. (Erwinia) nimipressuralis & - & - & ++ & - & Amp/Pen \\
\hline AS74B & XI & E. cloacae & - & - & ++ & - & Amp/Pen \\
\hline AS75 & XI & P. picketii & ++ & ++ & - & +++ & $\mathrm{Amp} / \mathrm{Tc} / \mathrm{Sm} / \mathrm{Km} / \mathrm{Nal} / \mathrm{Virg} / \mathrm{Pen}$ \\
\hline
\end{tabular}

$++/+++/=$ Sudan Black staining, in the carbon sources tested: sucrose, Suc; glucose, Glu; fructose, Fru; sodium propionate, Pro.

*Formerly Pseudomonas cepacia.

Amp, ampicillin; virg, virginiamycin; pen, penicillin; sm, streptomycin; km, kanamycin; tc, tetracyclin; nal, nalidixic acid; (-) no growth in the range of antibiotic concentration used

of the isolates were resistant to virg and/or nal. The percentage of isolates resistant to $\mathrm{sm}, \mathrm{km}$ or tc is lower than $30 \%$ in each case.

Among the 73 isolates with multiple resistance to antibiotics we emphasize the multiple resistance to seven antibiotics of $P$. picketii (AS14), $P$. aeruginosa (AS18), P. alcaligenes (AS77) and $B$. cepacia (AS18A) in Group A and P. picketii (AS75) and $P$. aeruginosa (AS63) in Group B. More than $95 \%$ of the isolates are resistant to amp or pen in the concentration range tested and about $48 \%$ are resistant to virg. The unknown proportions and specificity of antibiotics used in the fermentors of the alcohol distillery (sometimes they use a mixture called by them of 'cocktail'), do not allow in the present study to establish any plausible relation between the use of antibiotics in the distillery and the high numbers of antibiotics-resistant strains we isolated. Despite the personal information from technicians of the distillery chemical laboratory on greater use of penicillin, the possibility of some sort of selective pressure of this antibiotic on the microbiota environments here studied, deserves a deeper investigation; otherwise, several strains with multiple resistance to antibiotics, were also isolated from the soil under unburned sugarcane plantation (Table 2, site X, a place in a similar condition to a natural vegetation), and from all the other sites from groups A and B. Although there is a general agreement that the pool of resistance genes in the environment is amplified by the use of antimicrobial agents (12, see Science, 264: 359-393, 1994), the mechanisms of gene transfer between bacteria of different origins can spread the resistance genes 
efficiently in the microbial world, even in the absence of antimicrobial agents (10).

Microbial diversity and environmental bioindicators. Eighty-two bacteria strains were isolated from the sugarcane agroecosystem. In microbial diversity terms, 16 different genera and 35 different species of bacteria were isolated from the two groups of samples. Group A samples presented 12 different genera and 24 different species and Group B presented 10 genera and 21 species. The microbial diversity showed to be greater in samples related to the wastewater from the stabilization ponds (IV, 10 species; VII, 8 species; XII, 8 species) and the soil sample from the sugarcane plantation burned before harvesting (XI, 8 species). Odum's (18) classical observation that communities with low energy cost for maintaining the entropy (high respiration: biomass ratio), divert their energy supply into diversity, may be happening to the microbiota of the environments here investigated. A high respiration: biomass ratio observed in unproductive soil irrigated with vinasse, in the tableland soil of the Usina Japungu (15) gives support to this theory.

Discussion about biodiversity and environmental stress is controversial. Atlas (1984) pointed out diversity changes in response to environmental stress, showing both tendencies: (a) increase in diversity by selective toxicity, eliminating dominant organism; (b) diversity decreases by elimination of many species due to toxicity or increase in particular populations. Torsvik et al. (30) observed diversity decrease in perturbed soil due to agriculture, as compared to undisturbed environments. A molecular analysis of microbial diversity in Amazonia soils, based on PCR amplification of small-subunit rRNA, showed microbial population shifts related to deforestation in the Amazonian forest, with predominance of Bacillus and high $\mathrm{G}+\mathrm{C}$ gram-positive-like sequences in pasture and predominance of Clostridium and unclassified bacteria in the forest (4). Bacillus seems to be a 'natural indicator' of inhospitable environmental conditions and their endospore forming characteristic certainly explains their occurrence in these situations.

Among the isolates in Group A, sporulating bacteria are present only in site III, soil amended with vinasse. That is the case for the highly virulent animal pathogen $B$. anthracis, with high tolerance range to temperature $\left(-5\right.$ to $75{ }^{\circ} \mathrm{C}$ ), to $\mathrm{pH}$ acidity (from 2 to 8 ) and salt (up to $25 \% \mathrm{NaCl}$ ) (20). It is noteworthy to remind that vinasse causes salinization of soils. In
Group B, sporulating bacteria were found in all samples, except for VIII. Nevertheless, the highest percentage of sporulating strains was found in the borders of the large stabilization pond, in a place pemanently covered by wastewater (site IX). Bacteria strains with special ability to degrade recalcitrant compound, like Burkholderia cepacia (16), were found in the environments under greater selective pressure (sites IV, VII and XI). These altered conditions, of anthropic origin, may have contributed to an increase in the bacteria diversity and may also explain the greater occurrence of Bacillus, an endosporing bacterium. Atlas (3) conclusions are still certainly valid, as he said that though diversity measurements are a reflection of the dynamic status of an ecosystem, they do not show a cause and effect relationship between a particular level of stress and a particular species composition of the community.

\section{ACKNOWLEDGEMENTS}

To the Technical Directory of Usina Japungu, for allowing the sampling of all ecological material from the sugarcane agroecosystem used in the present investigation and to their former chemist and technician Ms. M. Helena S. Leite and Mr. Antonio J. da Silva, respectively, for the assistance with respect to antibiotics utilized in the alcohol distillery. To Dr. Janete Magalí de Araújo, for the standard strains from the Universidade Federal de Pernambuco collection and to IPT, São Paulo, for the Alcaligenes eutrophus and A. latus standard strains, all of whose support we gratefully acknowledge. This work was supported by funds from PADCT/FINEP and by a Scholarship to T.C.S.L. from Conselho Nacional de Desenvolvimento Científico e Tecnológico (CNPq).

\section{RESUMO}

\section{Bactérias isoladas de um agrossistema de cana-de-açúcar: produção potencial de polihidroxialcanoatos e resistência a antibióticos}

Neste trabalho, um agrosistema de cana de açúcar em tabuleiro litorâneo do nordeste do Brasil, foi rastreado para obtenção de bactérias capazes de sintetizarem polihidroxialcanoatos (PHA) usando sacarose como principal fonte de carbono. O potencial para sintetizar PHA foi testado 
qualitativamente por coloração, com Sudan Black, de colônias crescendo em diferentes fontes de carbono: sacarose, glicose, frutose, propionato e celulose. Num sistema de manejo típico do cultivo da cana-deaçúcar, a plantação é queimada antes de cada colheita e a vinhaça, subproduto da produção de álcool, é utilizada num sistema de fertirrigação causando, provavelmente, pressões seletivas sobre a microbiota dos ambientes naturais. Oitenta e duas linhagens de bactérias, pertencentes a 16 diferentes gêneros e 35 diferentes espécies foram isoladas. Os dados mostraram que 11 linhagens (13\%), 9 das quais pertencentes ao gênero Pseudomonas, apresentaram intensa coloração por Sudan Black em algumas das fontes de carbono testadas e mostraram, simultaneamente, múltipla resistência a antibióticos. Resistência a antibióticos, é uma característica vantajosa à produção biotecnológica de PHAs. O número total de isolados com múltipla resistência a antibióticos foi 73 , dos quais, $38 \%$ pertencentes ao gênero Pseudomonas. Entre os isolados, 86\% e 43\% cresceram na presença de $10-100 \mathrm{U} / \mathrm{ml}$ de penicilina e $100-300 \mu \mathrm{g} / \mathrm{ml}$ de virginiamicina. Estes antibióticos são utilizados na Usina em estudo. Os resultados sugerem que alguns ambientes do agrossistema podem ser considerados como habitats onde as bactérias estão submetidas a condições nutricionais desbalanceadas, contibuindo para estabelecimento de linhagens com habilidade potencial de produzir PHAs e, também, para o aumento da diversidade microbiana.

Palavras-chave: poli- $\beta$-hidroxialcanoato, PHA, resistência de bactérias a antibióticos, agrossistema da cana-de-açúcar, vinhaça.

\section{REFERENCES}

1. Allen, S.E.; Grimshaw, H.M.; Parkinson, J.A.; Quarmby, C. (eds.) Chemical analysis of ecological materials. Blackwell Scientific Publications, Oxford, 1974.

2. Anderson, A.J.; Dawes, E.A. Occurrence, metabolism, metabolic role, and industrial uses of bacterial PHA. Microbiol. Rev. 54: 450-472, 1990.

3. Atlas, R.M. Use of microbial diversity measurements to assess environmental stress. In: Klug, M.J.; Reddy, C.A. (eds.) Current perspectives in microbial ecology. ASM, Washington, 1984. p. $540-545$.

4. Borneman, J; Triplett, E.W. Molecular microbial diversity in soils from eastern Amazonia: evidence for unusual microorganisms and microbial population shifts associated with deforestation. Appl. Environ. Microbiol. 63: 2647-2653, 1997.
5. Byrom, D. Polymer synthesis by microorganisms: technology and economics. TIBTech. 5: 246-250, 1987.

6. Feinman, S.E. Antibiotics in animal feed: drug resistance revisited. ASM News, 64: 24-30, 1998.

7. Herbert, R.A. Methods for enumerating microorganisms and determining biomass in natural environments. In: Grigorova, R.; Norris, J.R. Methods in microbiology. Vol. 22. Academic Press, London, 1990. p. 1-39.

8. Holt, J.G.; Krieg, N.R.; Sneath, P.H.A.; Staley, J.T.; Williams, S.T. Bergey's manual of determinative bacteriology. 9th ed. Williams \& Wilkins, Baltimore, 1994.

9. Huddleston, A.S.; Cresswell, N.; Neves, M.C.P.; Beringer, J.E.; Baumberg, S.; Thomas, D.I.; Wellington, E.M.H. Molecular detection of streptomycin-producing Streptomycetes in Brazilian soils. Appl. Environ. Microbiol. 63: 1288-1297, 1997.

10. Kruse, H.; S申rum, H. Transfer of multiple drug resistance plasmids between bacteria of diverse origins in natural microenvironments. Appl. Environ. Microbiol. 60: 4015-4021, 1994.

11. Lafferty, R.M.; Korsatko, B.; Korsatko, W. Microbial production of poly- $\beta$-hydroxybutyric acid. In: Rehm, H.J. \& Reed, G. (eds). Biotechnology. VCH Verlagsgesellschaft, Weinheim, 1988, p. 135-176.

12. Levy, S.B. The antibiotic paradox. Plenum Press, New York, 1992.

13. Levy, S.B. The challenge of antibiotic resistance. Scient. Am. 278: 32-39, 1998.

14. Leaf, T.A.; Peterson, M.S.; Stoup, S.K.; Somers, D.; Srienc, F. Saccharomyces cerevisiae expressing bacterial polyhydroxybutyrate synthase produces poly-3-hydroxybutyrate. Microb. 142: 1169-1180, 1996

15. Luna, R.G. de; Grisi, B.M. Biomassa e atividade microbianas de solos cultivados com cana-de-açúcar, sob efeito da vinhaça. Rev. Nordest. Biol. 11: 15-29, 1996.

16. Madigan, M.T.; Martinko, J.M.; Parker, J. Brock, Biology of microorganisms. Prentice-Hall, Upper Saddle River, NJ, 986 p, 1997.

17. Mazzola, M.; Cook, R.J.; Thomashow, L.S.; Weller, D.M.; Pierson, L.S. Contribution of phenazine antibiotic biosynthesis to the ecological competence of fluorescent pseudomonads in soil habitats. Appl. Environ. Microbiol. 58: 2616-2624, 1992.

18. Odum, E.P. Fundamentals of ecology. W.B. Saunders Co., Philadelphia, 1971.

19. Parkinson, D.; Gray, T.R.G.; Williams, S.T. Methods for studying the ecology of microorganisms. IBP Handbook $\mathrm{n}^{\circ}$ 19. Blackwell Scientific Publications, Oxford, 1971.

20. Paul, E.A.; Clark, F.E. Soil microbiology and biochemistry. Academic Press, San Diego, 1989.

21. Qi, Q.; Rehm, BH; Steinbuchel, A. Synthesis of poly(3-hydroxyalkanoates) in Escherichia coli expressing the PHA synthase gene phaC2 from Pseudomonas aeruginosa: comparison of PhaC1 and PhaC2. FEMS Microbiol. Lett. 157: 155-162, 1997.

22. Ramsay, B.A.; Lomaliza, K.; Chavarie, C.; Dubé, B.; Bataille, P.; Ramsay, J. Production of poly-( $\beta$-hydroxybutyric-co$\beta$-hydroxyvaleric) acids. Appl. Environ. Microbiol. 56: 2093-2098, 1990.

23. Sambrook, J.; Fritsch, E.F.; Manatis, T. Molecular cloning: a laboratory manual. 2th ed. Cold Spring Harbor Laboratory Press, Cold Spring Harbor, NY, 1989. 
24. Schegel, H.G.; Lafferty, R.; Krauss, I. The isolation of mutants not accumulating poly- $\beta$-hydroxybutiric acid. Arch. Mikrobiol. 71: 283-294, 1970.

25. Slater, S.C.; Voige, W.H.; Dennis, D.E. Cloning and expression in Escherichia coli of the Alcaligenes eutrophus $\mathrm{H} 16$ poly- $\beta$-hydroxybutirate biosynthetic pathway. Bacteriol. 170 : 4431-4436, 1988.

26. Sneath, P.H.A.; Mair, N.S.; Sharpe, M.E.; Holt, J.G. Bergey's manual of systematic bacteriology. Vol. 2. Williams \& Wilkins, Baltimore, 1986.

27. Steinbüchel, A. Recent advances in the knowledge of the metabolism of bacterial polyhydroxyalkanoic acids and potential impacts on the production of biodegradable thermoplastics. Acta Biotechnol. 11: 419-427, 1991.

28. Tauk, S.M.; Schoenlein-Crussius, I.H.; Petenate, A. Modelo ecológico dos nutrientes, microrganismos e atividade enzimática de solo sob vegetação de cerrado tratado com vinhaça, Corumbataí, SP. Rev. Microbiol. 21: 99-108, 1990.
29. Thomashow, L.S.; Weller, D.M.; Bonsall, R.F.; Pierson, LS. Production of the antibiotic phenazine-1-carboxylic acid by fluorescent Pseudomonas spp. in the rhizosphere of wheat. Appl. Environ. Microbiol. 56: 908-912, 1990.

30. Torsvik, V.L.; Daae, F.L.; Goksфyr, J.; Sfrheim, R.; Ævreas, L. Diversity of bacteria in soil and marine environments. In: Martins, M.T.; Sato, M.I.Z.; Tiedje, J.M.; Hagler, L.C.N.; Döbereiner, J.; Sanchez, P.S. (eds.) Progress in microbial ecology. SBM/ICOME, São Paulo, 1997, p. 115-120.

31. Trevors, J.T.; Barkay, T.; Bourquin, A.W. Gene transfer among bacteria in soil and aquatic environments: a review. Can. J. Microbiol. 33: 191-198, 1987.

32. Van Elsas, J.P.; Pereira, M.T.P.R.R. Occurrence of antibiotic resistance among bacilli in Brazilian soils and possible involvement of resistance plasmids. Pl. Soil, 94: 213-226, 1986.

33. Williams, S.T.; Vickers, J.C. The ecology of antibiotic production. Microb. Ecol. 12: 43-52, 1986. 